International Journal of Korean Humanities and Social Sciences

Vol. 5/2019

DOI: http://dx.doi.org/10.14746/kr.2019.05.04

\title{
WHAT IS AN ORAL HEROIC EPIC POETRY? - OVERCOMING THE LIMIT OF THE ILIAD
}

\section{JONG-SEONG PARK, Prof.}

Dept. of Korean Language and Literature, Korea National Open University, 86 Daehak-ro, Jongro-gu, Seoul, South Korea pjs551@knou.ac.kr

ORCID: https://orcid.org/0000-0002-1397-6817

\begin{abstract}
The ancient Greek epic Iliad, including the oral epic and the written epic, has enjoyed a solid status as a 'heroic epic' (or 'narrative poetry') of European literature. But if a reader takes look at the general aspects of the heroic epic of oral tradition, it turns out that Iliad is not a typical work of a typical epic, but rather an individual one. Because the birth, trials, performance, and ending of a hero's life are divided relatively evenly, and the general pattern of transferring the hero's life to the heroic epic of oral tradition can be found in such cases as Manas, Jangar, Gesar and Mwindo.
\end{abstract}

Keywords: Heroic Epic of Oral Tradition; Iliad; Hero's Biography; Manas; Jangar; Gesar; Mwindo. 


\section{구비영웅서사시란 무엇인가? - 일리아드의 한계를 넘어서}

국문초록: 구비전승되는 서서시와 기록된 서사시를 포함하여 고대 희랍의 서사시 일리아드는 유럽 문학사에서 서사시의 전범으로 확고한 지위를 누려왔다. 그런데 구비영웅서사시의 일반적인 양상을 검토하면 일리아드가 일반적인 서사시의 대표적 작품이 아니라 개별적인 양상을 띠는 작품으로 확인된다. 왜냐하면 영웅의 출생, 시련, 영웅적 과업의 수행, 결말 등이 비교적 균등하게 배분되어 영웅의 일대기를 구비영웅서사시로 전승하는 일반적인 양상을 마나스, 장가르, 개사르, 음윈도 등의 사례에서 확인할 수 있기 때문이다.

핵심어: 구비영웅서사시; 일리아드; 영웅의 일대기; 마나스; 장가르; 게사르; 음윈도.

\section{CZYM JEST USTNY POEMAT HEROICZNY? - PRZEKRACZAJĄC GRANICE ILIADY}

Abstrakt: Starożytna grecka epopeja Iliada, zarówno w wersji pisanej jak i ustnej jako poemat heroiczny (lub jako poemat narracyjny) zajmuje poczesne miejsce w literaturze europejskiej. Jeśli jednak przyjrzeć się ogólnym aspektom ustnych poematów heroicznych, okazuje się, że Iliada nie jest ich typowym przykładem i wykazuje pewne cechy charakterystyczne. Świadczą o tym m.in. równe rozłożenie etapów życia herosa, tj. narodziny, próby, działalność oraz śmierć. Ogólny wzorzec przenoszenia życia herosa do poematu heroicznego w przekazie ustnym może być także zaobserwowany w takich dziełach jak Manas, Jangar, Gesar czy Mwindo.

Słowa klucze: Poemat Heroiczny w Przekazie Ustnym; Iliada; Biografia Herosa; Manas; Jangar; Gesar; Mwindo.

The epic of Homer Iliad gains recognition as a representative model of the epic poetry, so called 'Epic'. But comparing to the oral heroic epic poetry of other nations as I did before (cf. Park Jong-Seong 1994; 2005), it is a question whether this epic can be defined as a model of epic poetry. I would like to introduce this discussion with a following citation of Cho Dong-il (조동일 2002: 44-45): 


\section{IJKHSS 5/2019}

"I do not agree with the notion that Iliad and Odysseia, the ancient greek epic poetry of B.C. 9, are the model of epic. Struggles of heroes like Achilleus show well the way of thinking of ancient people. However, it does not describe whole lives of them but starts from the middle of it whose characteristics are long sentences with too many words of ornaments. I think that Homer known as the author had accepted oral information and reproduced it by his own way. It is a secession of the original form that one condensed and extended the genuine version in the process of recording"1

It clearly appears that Iliad does not fit to the general characters of epic poetry, especially oral hero epic poetry, in the part about a birth of hero. There is any part to sing on the birth and death of Achilleus. However, oral tradition on the birth of Achilleus can be found not in epic poetry, but in the Metamorphoses and historical resources. By the way, the birth of Achilleus, so to speak forming a relationship between goddess of sea Thetis and king of Phythia Peleus, and the incident of Stics river foretelling his destiny were mixed with Iliad and reproduced in the Greek mythology and films on it. So it makes people believe wrongly that Iliad is the epic singing on an history of the ancient hero Achilleus. No matter whether it is an ancient epic, an medieval epic, or a epic in modern transition era oral hero epic poetry has to treat full history of an hero and then it can be accepted that it fulfills basic conditions of epic poetry. We can check this point out from the oral hero epics of other countries in the world where passing down had happened and is happening now

Iliad has characters of oral epic and fiction epic so that it could take naturally a role of a representative model of epic in the European civilization. It could not exist a obstacle for Iliad to play the role in the countries where use the Latin language as common written language, accepted the Christianity, common religion of medieval period and formed the common civilization. Because in such country oral tradition of their own oral hero epic had ceased to exist and had

\footnotetext{
1 "기원전 9 세기경에 기록되었다고 추정되는 고대 그리스서사시 <일리아스> (Ilias)와 <오딧세이아> (Odysseia)는 서사시의 전범이라고 하는데 그럴 수 없다. 아킬레스 (Achilles) 같은 영웅의 투쟁은 고대인의 사고방식을 잘 보여주지만, 일생의 전폭을 다루지 않고 사건의 중간에서 시작되며, 말이 너무 많고 수식이 과다해서 길게 늘어난 점이 특이하다. 작자라고 알려진 호메로스 (Homeros)가 구전을 받아들여 자기 나름대로 재창작한 결과가 그렇게 나타났다고 생각한다. 기록과정에서 이루어진 축약뿐만 아니라 확대도 원형 이탈이다."
} 
transformed into recorded epic. Otherwise, oral epic had been dissembled and spread out by part. But when the research area was getting widen to other regions it is confirmed that the various kind of oral epic poetry was handed down to many nations over the world in many forms. Therefore, in order for Iliad to take a position of the representative model of all epics it needs to contain a logic which include all epics. As Bowra (1966: 101) states, "of heroes famed for resource Odysseus is the most complete". Let's take a look some cases related to it from discussions of A. B. Lord.

In the discussions over procedure of formation of Iliad we can see some similar aspects with Kalevala well known as the Finnish modern national epic. Elias Lönnrot collected and reproduced many short epics, he completed Kalevala in 1836 and in 1849 (cf. F.J.Oinas 1978: 285). In the case of Kalevala, we can compare it with Iliad. Kalevala is also a fiction epic that succeeded the tradition of oral epic like Iliad. Focusing on Väinämöinen, Kalevala treats his birth, incidents related with Ilmarinen and Lemminkainen, and his full life. However Iliad is different from the point of view that it just focuses on the part of certain incidents. It is the case showing difference whether newly produced epics, based on orally handed down epics, inherited a whole life of hero kept firmly by oral hero epic, or not. In general point of view, Kalevala fulfills relatively the requirements of oral epic. A. B Lord also recognizes similarities between the two epics, but focuses his point on stressing that they are very different from the point of the manner of composition.

In the discussion about a case of long oral heroic epic which included simple epic like Iliad with the example of Gesar, Mwindo, Manas, and Alpamish, Iliad was taken as the kind of oral epic which can hardly identify the editor or collector and just is orally handed down. In Jangar or Gesar, Mwindo, Manas, and etc. materials handed down are collected and edited by certain writers. However, it did not pay attention to the point that they were not created in the way of summarizing oral epics and exaggerating some incidents like Homer. It is suspicious that they did not recognize the clear distinctiveness but just developed convenient discussions. Also, they categorized epic of Homer as same kind as Serbo-Croatian epic, Das Nibelungenlied, La Chanson de Roland, and etc. In result they disclosed the view point to isolate Kalevala.

Whether Iliad is oral epic or written epic, it has played the role of representative model of epic. Applying the Formula Theory to 
Iliad, it has been used to consolidate the unique position as oral epic of long tradition. Utilizing an advantage of written down epic in the early period and stressing special plots and formula used by epics of peripheral nations they tried to convince that Iliad is an original form of oral epics of peripheral nations. They emphasized that a great poet like Homer reproduced it as literary work of high quality through collecting and editing to consolidate the position of Iliad as a representative model of written epic.

There is a tendency to interpret short oral epic that it does not properly satisfy conditions for epic because they set the conditions of oral epic on basis of time of play or whole volume considering that Iliad has 15,692 lines and Odyssey has 12,110 lines. ${ }^{2}$ According to this point of view, Jangar with 35,000 lines, Kalevala with 22,795 lines, and Manas, whose sentences are 250,000 in the wood blockprinted book can be genuine long oral epics more than Iliad and Odyssey. Whether Iliad had such intention or not, it is a bad influence caused by westernized discussions on oral epic.

They make a mistake to accept that the ancient Greek epic is a representative model of epic in order for their national epic to put on the same stage with the Greek epic. They just emphasize that these two epics are on the same level to prove the value of their own national epic. Such effort is hard to understand without any consideration how the ancient Greek epic and their national epic are different (cf. 조동일 Cho Dong-Il 1991: 123-124).

If we take Iliad as a oral heroic epic that is collected the existing epics and reproduced by one person, it becomes clear that it does not fulfill the condition for oral epic comparing to Kalevala which has a full life story of hero. The background of forming Jangar, Manas, and Marko Kraljević are enough to recognize them as oral heroic epic because they were constructed naturally by the way of creating poem or gathering short epics. But Iliad is disqualified from epic handed down with tradition until present or not long time ago. When Iliad compares to Das Nibelungenlied they may have

\footnotetext{
${ }^{2}$ In result of it, it is general tendency that whole volume of epic was put in head of it to highlight the value of Jangar and Manas. They took such methodology to get acknowledgment of argument that it is in the same stage with epics of Homer. In the case of Manas, they recognize that the volume and aesthetical realization of it stands comparison with Iliad and they give the nick name of 'Step Iliad'. However, the very standard is finally Iliad. In the case of Eastern Europe like Poland, Serbia, Romania, and etc. it is a general tendency of discussion considering that oral epic is long epic. Of course, they deal with rhythmical change.
} 
similarities because it does not have only a character of recorded epic ceased tradition of oral inheritance, but also has been re-edited and inherited by many copies. But we can find out definitive difference between because Das Nibelungenlied contains the whole life of hero. We can see here the defectiveness of Iliad. ${ }^{3}$

Of course it is hard to exclude the possibility that birth and death of the ancient heroes like Achilles could be inherited until certain period. We can find out such possibility from Metamorphoses by Ovidius which tells about the birth of Achilles in detail because it has rules of versification (cf. 이진성 Lee Jin-Sung 2004). On the other hand, it is possible to accept the heroic epical character of Iliad. The birth of Iliad and his childhood from other sources handed down until now can be used as the introduction of epic Iliad. Still there remains a question. Can it be equivalent to Homer's Iliad? Long

\footnotetext{
${ }^{3}$ In criticism of epic poetry on the basis of Iliad it is a clear fact that we can meet often with deficient elements. For Iliad it needs to find out correlative similarity with the region where handing down of oral epics is active to awaken characteristics of oral epic discontinued its inheritance. Relating the vivid oral epics of the central Asia with Iliad has geographical and historical probability so that it becomes a good item for comparative research. By the way, there was difficulty in relating directly with Turkish oral epic and it needed to find mediate regions. At this moment SerboCroatian epics of which research has been done got to be highlighted. A. B. Lord has played an important role. He applied the result of his famous work Singers of Tales to Iliad and Turkish epics. However, his research has a weak point. Muslim gave him materials of Serbo-Croatian epics. As compares the Serbo-Croatian oral epic with the central Asian epics, A. B. Lord estimates Marko Kraljević as exceptional among Marko Kraljević, Janković Stojan, and Dulin Ibrahim which are the essential of Serbo-Croatian epic. It means that he used vocal materials of a Muslim wandering minstrel. Therefore, Marko Kraljević among Serbo-Croatian epics is taken as a exceptional work containing relatively minimal similarities with central Asian and western European epics. The Serbo-Croatian epics given by a Muslim wandering minstrel has relatively close relationship with Turkish oral epic which conquered the Balkan area. Lord committed faults to accept materials with close similarities as core of Serbo-Croatian epics and to take Marko Kraljević as an exceptional case. When we look into 'Song of Marriage' of Marko Kraljević it becomes clear. This part of the epic set different assumption with western and central Asian epics. Marko was not kidnaped in relation with marriage and did not fall into dangerous situation. Difficulties in marriage were solved without any trouble. Here, Marko's punishing is very severe. With exception of Sultan, he punished enemies severely. 'Song of Marriage' is to be seen as very exceptional case for western researchers. In result of it, the possibility that Serbo-Croatian oral epic had been formed by the deep influences of western epics and central Asian oral epics was stressed out. It caused big damages to the individuality of Serbo-Croatian oral epic. Of course, this discussion does not deal with the issue of origin. But it is a problem that the discussion of Lord highlighted foreign elements of formation and it magically disarms debate on origin.
} 
enough and excellent as Homer's Iliad? Exuberant in depiction and narrative as Homer's?

Iliad can be a work composed of selection of tales spreaded orally by Homer (이진성 Lee Jin-Sung 2004: 292), or a work collected various short stories on the Trojan war (Lord 1991: 107). As matter of fact, it can not see that the epic Iliad was shortened and summarized by Homer because it sings fully the whole life of Achilles (Lord 1991: 109) ${ }^{4}$. A. B. Lord affirmed that Homer is doubtlessly a poet singing oral epic on the basis of utilization of formula and its repeating - "Homer learned these as a traditional singer, and with the mastery of genius he retold them in traditional form in the Iliad and Odysseus." (1991: 103). However, Lesky does not recognize Homer as a wandering minstrel. He argues that his writing was only a new thing, "that the poet [Homer] had formed his work in writing. (...) But writing was something new, hitherto unheard of." (1991: 97). It is not clear whether Homer is a wandering minstrel or simple editor, or a talented poet who got used to the tradition of oral epic. Rather it is more natural that understand Iliad as a work of oral epics inherited until that time and re-edition of writing handing down to which Homer's literal talent was added.

Related to this, it is necessary to urge shortly that epics complemented details of Iliad and Odyssey from B.C. $6-7$ are inherited in documents even not whole part of it. Song of Cyprus People, known as written by a poet from this island, is the work singing 12 parts of incidents before Iliad, Song of Ethiopians by Arctinus of Miletus in B.C. 7 is the work singing famous incidents in 5 parts after the funeral of Hectos. In B.C. 7 Little Iliad of Lesches wrote mainly about the incidents when the wooden horse entered into Troy, The Collapse of Ilion presumably written by Arctinus of Miletus is composed of 2 parts focusing on the collapse of Troy (cf. 이진성 Lee Jin-Sung 2004: 357-358). It is clarified that numbers of epics related to Iliad of Homer are mainly reconstructed or created by certain authors. These facts prove that various epics with theme of the Trojan War were recreated by many writers.

What does such fact mean? It might mean that such heroic epic like Iliad did not inherit from the tradition of oral epics as it is. So

\footnotetext{
${ }^{4}$ Author believes that it is very likely that Homer never sang the songs of the return of "Odysseus from Troy or of the wrath of Achilles at the great length in which appear in our Iliad and Odysseus."
} 
there were such general tendency that poets selected and gathered short epics orally handed down and legends and then recreated as their interests. If so, it is highly possible that most of ancient Greek epics, not only Iliad of Homer, were created with special interest and literal talent of writer. Iliad of Homer is composed of not a history of hero, but rage and battles of the hero Achilles during certain period of the Trojan War. Homer is probably a kind of epic poet who selectively gathered materials of oral epics and legends and created written epic with his own talents. According to the reason why some famous writes like Sappho after Homer actively accepted his forms of expression and rhythm and used them properly, the assumption that Iliad had different character from the form of expression and the rhythm in the ancient Greek period may gain probability ${ }^{5}$. Even though its character of oral epic poetry we do not say that Kalevala of Elias Lönnrot is a oral epic poetry. Therefore, Iliad of Homer is not an oral heroic poetry in the normal sense of the word.

In Korea, plenty of shaman ritual epic are the cases of oral heroic poetry. The Korean shaman ritual epic deals fully with whole life of heroes so that it can satisfy the requirements of oral heroic epic in other regions. In my opinion, we can find out excellent oral heroic epic among many Polish epic ballad. It is necessary that find out polish oral heroic epics and highlight the meaning of them to overcome the limit of the consolidated epic poetry of the old Europe.

Therefore, we can estimate that Iliad of Homer is reproduced exceptionally in result because it did not follow the general rules of oral heroic epic dealing with whole life of heroes. A bit radically saying, it is more natural that Iliad of Homer is not a representative model of all epics, but a special work influenced greatly on epic poetry. I admit that it has not small influences on the history of the western literature as a source of literature and Iliad as it is achieved the high level of literature in that times. But it is hard to understand the effort to define as the model of all epics expanding the extent of achievement. What oral heroic epic sings one scene exaggeratively as possible and shows psychology of people through action is not a condition of oral heroic epic comparing with the cases of other oral

\footnotetext{
${ }^{5}$ Konrad Wallenrod of Adam Mickiewicz (for this article version printed in 1992 was used), who is respected as a national poet, shows conjunction of rhythm of Polish traditional oral epics with the rhythm of Iliad, which shows created epics in new forms. It played a role of norm for created epic in Poland. I assume that Homer was in the same position with Adam Mickiewicz.
} 
epics in exclusion of Arabic epic. Rather it is only a exceptional symptom. I think that Iliad of Homer does not play a role of the representative model or the origin of epic any more.

\section{Bibliography}

Bowra, Maurice C. 1966. Heroic Poetry. New York: St. Martin's Press Lord, Albert B. 1973. The Singers of Tales. New York: Atheneum.

Lord, Albert B. 1991. Epic Singers and Oral Tradition. N.Y. : Cornell Univ. Press

Mickiewicz, Adam. 1992. Konrad Wallenrod In Powieści poetyckie, Ksiegi narodu polskiego i pielgrzymstwa polskiego. Warszawa: Czytelnik

Oinas, Felix F. (ed.). 1978. The Balto-Finnic Epics. Introduction to the World's Great Folk Epics. Blooming: Indiana University Press.

박종성 (Park Jong-Seong). 1994. 무속서사시 연구의 새로운 관점 (Musog seosasi Yeongu-ui saeroun gwanjeom). 구비문학연구 (Gubi Munhag Yeongu) 1: 275-316.

박종성 (Park Jong-Seong). 2005. 한국의 본풀이와 구비영웅서사시 비교론, 그 두 측면. Hangug-ui Bonpuriwa gubi yeongeung seosasi bigyoron. 한국문학논총 Hangug Munhag Nonchong, vol. 41 (2005.12): 21-52.

이진성 (Lee Jin-Sung). 2004. 그리스 신화의 이해 (Geuriseu Sinhwa-ui Ihae ). 서울 (Seoul): 아카넷 (Akanet).

조동일 (Cho Dong-Il). 2002. 세계문학사의 전개 (Saegyemunhaksaui jeongae). 서울 (Seoul): 지식산업사 (Jisig-saneobsa) 